\title{
Afghanistan as a Land Bridge between Central Asia and South Asia for Economic Cooperation: Challenges and Opportunities
}

\author{
Masom Jan Masomy ${ }^{1}$
}

\begin{abstract}
Energy Security is important for healthy economy of any country. Thus countries try to have long term and stable arrangements to meet their energy requirements. Undoubtedly Central Asia is a rich source for energy. However, ease of transportation is a connected issue. Accordingly, the Energy-rich Central Asia has been making attempts to have access to global markets through land and sea from the time nations in the region gained independence from erstwhile USSR. South Asia, on the other hand, is energy starved and is keen to have access to plenty of natural resources of Central Asia through bilateral and multilateral relations with the five CARs. Therefore, the regional connectivity between Central Asia and South Asia has been a top issue in the recent two decades despite various challenges and geopolitical constraints. Benefits of enhanced connectivity are obvious: Access to ports in South Asia would energize the economies of CAR nations, while connectivity with fast-developing South Asia would expand market opportunities mutually.

In this paper, the ancient cultural and trade ties between South Asia and Central Asia and the current demands of connectivity have been discussed based on ancient historic links and geopolitics of the region. The role of Afghanistan as a land bridge in the region has been analyzed to provide for regional economic integration between Central Asia and South Asia. Also, it has been pointed out to that the common challenges need to be removed and the opportunities need to be availed for multilateral partnership and for economic cooperation and development between the two regions.
\end{abstract}

Keywords: CAR, Connectivity, South Asia, Afghanistan, Cultural ties, Economic integration

\footnotetext{
${ }^{1}$ Masom Jan Masomy is an MA International Relations ( $2^{\text {nd }}$ year) student at UMISARC Department of South Asian Studies, Pondicherry University, Puducherry, India.
} 


\section{Afghanistan as a Land Bridge between Central Asia and South Asia for Economic Cooperation: Challenges and Opportunities}

\section{Introduction}

Energy is life blood for economy of any country. Central Asia has been a rich source for meeting the requirements of South Asian countries. Historically, Central Asia and South Asia have a shared long history of culture, trade, migration and interactions of civilizations. Impacts of civilization have been left on the entire region by ancient monarchs and empires. Alexander the Great, Genghis khan, Tamerlane, Arab conquerors, Hindu kings, Britain and Russia made their empires in Central Asia expanding into South Asia and visa-versa. They have left the heavily populated region with ups and downs, in different periods of time, which have shaped the history of this region. But as times changed, the advent of globalization and the advancement of technology made the world as closer as a village for exchange of ideas, thoughts, information, communications, interactions, goods and services amongst humankind. However, the concept of regionalism, with due pressures of globalization, appear to be driving South Asia and Central Asia for multilateral partnership.

Recently, Central Asia has attracted global attention for economic reasons too. South Asia due to the natural proximity with Central Asia is willing to reach out to the natural resources of five CARs, and also seeking to enhance multilateral economic cooperation with the CARs. In this context, the geographic position of Afghanistan is one of the key factors that could play the role of a land bridge between Central Asia and South Asia. Hence, the historic importance of Afghanistan and its geostrategic and geopolitical significance needs perspective analysis. The multilateral economic cooperation which is possible through Afghanistan for regional integration demands that opportunities are utilized properly, and the existing challenges are jointly resolved in the region - so as to enable the route of regional connectivity and shared prosperity.

\section{Historical Perspective}

Due to the geostrategic location, Afghanistan had always been of immense interest to great empires like Greece, Arabs, Turkish, Moghul, as well as the British and the Russian for expanding their sphere of influence. Alexander the Great attacked Afghanistan in the fourth century BC. In the seventh century AD, Arab conquerors expanded their rule to Central Asia and Afghanistan through the Indian subcontinent in order to spread Islam in the region. Prior to this, Hinduism and 
Buddhism were influential. Hindu kings were also ruling over Kabul at a time. The present day Uzbekistan, historically known as Bukhara, had control over the northern part of the country. In 1219 AD, Genghis khan, a Mongol Emperor, stepped into Afghanistan and waged destructive wars. At the end of fourteenth century, Tamerlane (Timur the Lame), a Torco-Mongol emperor, conquered large parts of that country and later moved towards Delhi. In 1507, the Uzbeks came to power in Central Asia, Herat was named as their capital in western part of Afghanistan. The eastern realm of the country and south of Hindu Kush were ruled by Moghul Empire from the sixteenth century. Meanwhile, the western part, particularly Herat, was controlled by Persian dynasty (McCauley, 2002).

In the nineteenth century, both Great Britain and Russia made attempts to expand their imperial role into the region extensively. British India had fears of Russia's expansionist policy towards Indian subcontinent that was seen as a direct threat to the colonial power in South Asia. Afghanistan played its role as a buffer state between these two giants, known as the Great Game in the history (Khan, 1998). Though the country's role between the two colonial powers was like a bridge - if it was crossed by anyone, they would enter to the other's region during the great game era.

Afghanistan, however, is a landlocked and mountainous country but has still kept the historic character of connectivity known as crossroads of Asia. Based on geographic location, Afghanistan shares 2,370 km-long border with three Central Asian states - Uzbekistan, Tajikistan and Turkmenistan to its north. To the south-west and west is Iran, and the Durand Line is an informal line between Afghanistan and present-day Pakistan to the south. Towards south-east, it is bordering with China through Wakhan corridor in the Pamirs, a strategic point connecting the two countries. (Khan, 1998, p. 490)

McCauley (McCauley, 2002) mentions about three distinct geographic regions "the central highlands, the northern plains and the south-western plateau." (p. 3) according to him, the central highlands with its many high mountain peaks, narrow valleys and with important strategic passes including Khyber pass give access to present-day Pakistan and India, southeast of Kabul. The northern plains run from Iran to the Pamirs- close to the Tajikistan's border which are the parts of Central Asia steppe. 
South Asia and Central Asia are two proximate regions. Afghanistan as a linkage country has strong cultural relationships to both sides throughout its history. As per the historical facts and documents, the lifestyle of the people of Central Asia has been nomadic with people migrating to Indian subcontinent through Afghanistan. The great empires from the north and south have also promoted cultural exchanges, transit and trade, and aided migration process from Central Asia to South Asia. It is said that the cultural and economic ties were improved during Greek and Saka rule and got the momentum at the time of Kushana Empire between India and Central Asia (Bhat, Mubarik, \& Kushwaha 2018). Furthermore, Afghanistan-India have been enjoying centuries-old relations - dating back to the Indus valley Civilization. The Mauryan and Asoka Empires introduced Buddhism in the region.

Afghanistan, as an initial route, also served different conquerors. The religion of Islam in the seventh century came to Afghanistan and later spread to India in the tenth century. Sher Sha Sori, an Afghan ruler who had also ruled over northwest parts of India in the sixteenth century built a Grand Trunk Road in India (Archiwal, 2019) This marks the historic relations of both countries and denotes the key factor as to how cultural ties and trade transactions have been passed and carried out through Afghanistan from Central Asia to South Asia and vice-versa. Historic events and facts prove that Afghanistan has remained as the focal point connecting Central and South Asia, and the culture and tradition have been developed amongst the people through its unique geographical position in history. Overall, its geographical position is suited to fostering culture, trade, people to people contacts and economic cooperation generating productive results for sustainable development and economic boom.

\section{Regional Connectivity and Economic Development for Central and South Asia:}

\section{Afghanistan as a Factor}

\section{Central Asia}

In today's globalized world, state actors and non-state actors are making tireless attempts to create an atmosphere of cooperative collaborations as a person, as a community, as a state and as a region. The idea of globalization is defined comprehensive in itself that has affected the sovereignties and territorial borders of states. The twenty first century of globalization has allowed human beings to 
open the way for economic goals; support investment, promote economies, open links of transactions, provide facilities to trading opportunities, increase capacities, share information, build infrastructures, provide security for viable partnership, strengthen bilateral and multilateral relations, and so on. All these interactions have helped in the fight against poverty, illiteracy, joblessness, corruption, instability, and led to a developed and democratized society in which the human rights of every individual, family and community could be protected-but still much more needs to be done. To that end, South Asian and Central Asian states as fast-developing nations need to take solid steps for economic engagement for enhancing quality of life and prosperity in the region.

Both the regions have geographical proximity to boost their national economies within the framework of regional integration. Political geographer and strategist Nicholas J. Spykman, in the context, says: "that Geography is one of the key factors in shaping foreign policy priorities. The primary attributes of a geographic region are: its location, topography, climate and natural (energy) resources." (Nicholas J. Spykman, n.d. p. 31). They all have impact on its sociocultural and political milieu. By and large, the geostrategic location of landlocked Central Asia has established economic and trade opportunities to support geo-economic efforts. Dhaka (Dhaka, n.d.) emphasises the interdependence between national and global economies (p. 63). When five Central Asia Republics (CARs) - Tajikistan, Turkmenistan, Uzbekistan, Kazakhstan and Kyrgyzstan became independent after the disintegration of Soviet Union in 1990s, they started to take immediate strides towards self-determination and economic development. The 9/11 attacks in 2001 and subsequently the declaration of war on terror by US-led coalition changed the global order quickly. Security issues alongside politics and economics came into sharp focus of the world. And the new emerging geopolitical dimensions forced state actors to reconsider a number of issues in the sphere of international relations. For instance, bilateral and multilateral cooperation along with interactions and developmental economic strategies for engagements were revitalized by state actors based on foreign policy agendas. Central Asia Region received utmost attention owing to its geostrategic position following the $9 / 11$ attacks since the landlocked region of five republics has a unique geopolitical location between Russia and China. Analyzing world political milieu, US has mostly turned its peculiar attention to the Central Asia's five republics through a strategy of "Greater Central Asia" so as to contain the rising influence of China and Russia. Involvement 
of major powers like US, China, Russia, India, Pakistan, Iran, Turkey and European Union is the beginning of New Great Game in the region of Central Asia in order to secure their strategic interests beyond (Kaushiki, 2013).

Pertaining to natural resources, Central Asia enjoys natural energy potential capable of meeting the needs of global markets. Abundance of natural energy resources like Reserves of hydrocarbon and gas have provided an opportunity for sub-regional and regional connectivity. Hydropower sources, deposits of coals and uranium are additional resources to offer to the global market. Excellent wind and sunshine regime serve the region for the large-scale conventional and thermal wind and solar power potential. All these resources of CARs can result in a major change for economic growth. These provide opportunities for trade and transit possibilities to global markets. Asian Development Bank [ADB] (2010) points out about natural resources of CARs as follows:

Kazakhstan, Turkmenistan, and Uzbekistan already export oil and natural gas via pipeline and as liquefied natural gas. The Kyrgyz Republic and Tajikistan hold significant hydropower resources that could be tapped to market electricity for Afghanistan, the People's Republic of China, Iran, Pakistan, and the Russian Federation. Kazakhstan is a world leader in coal production, and Kazakhstan and Uzbekistan are among the top 10 nations in known uranium reserves. (p. 51)

Central Asia is far richer in natural gas. In 2005, Kazakhstan, Turkmenistan and Uzbekistan found themselves among the top twenty five world leaders in natural gas production, and also ranked top twenty in exports and proven reserves. Central Asia is planning to build transmission system for the energy and power exports to the region and rest of the world. The new electricity transmission networks, and gas and oil pipelines will enable Central Asia to play vital role in global economy. In particular the Kyrgyz Republic and Tajikistan possess hydropower potential, and other three countries have plenty of resources of oil, gas and coal (pp. 55-59). The dynamics of economic development is only dependent on peace and stability in the region. The most significant need for South Asia is to improve rooted links of cooperation, transition and trade with Central Asia and to pave the way for regional connectivity. South Asian countries, particularly Afghanistan, India and Pakistan, can together enhance their presence in Central Asia for mutual benefit and economic growth. 


\section{India}

India, according to Adnan and Fatima (Adnan \& Fatima, 2015) is the world largest democracy, second densely populated nation of the world, having the third largest standing army, fourth largest air force, and fifth largest navy in the world. India also is seeking to get permanent membership of UN Security Council and is making attempts to achieve status of regional and global power.

For India, relationships with the five Central Asian Republics began from 1990s after dissolution of the Soviet Union. Since then, India has established bilateral and trade links with these five republics in pharmaceutical sector, textiles, metallurgy, chemicals, hydrocarbons, mining processing, construction and industrial production. Kothari notes that relations of India and Central Asia Republics (CARs) became more strong in the twenty first century and very importantly from 2012 (Kothari, 2018). India -the emerging power, is obviously concerned to have access to Central Asia with the foreign policy objective to protect political and economic interests in the region. India appears to contest with regional rivals (China and Pakistan) to build a favorable stage in the emerging multipolar system of the world. The reality of new Great Game is the struggle amongst powers to gain access to the wealth and natural resources of Central Asia. India and Pakistan are also the biggest markets of consuming energy for whom the Central Asia energy resources are reachable easily.

During the tenure of Prime Minister Manmohan Singh, India and Kazakhstan signed an agreement of nuclear cooperation by which Kazakhstan agreed to supply 2,100 tons of uranium to India until 2014, and later both countries signed another agreement for "Cooperation in the Field of Peaceful Uses of Atomic Energy" (Menon \& Rajiv, 2019). In 2015, India signed a new agreement with Kazakhstan for the purchase of more 5000 tons of uranium till 2019 to secure its energy interests, and currently both sides are in the process of the third agreement to increase supplies of uranium to 7500-10000 tons. (Menon \& Rajiv, 2019). According to World Nuclear Association (WNA), Kazakhstan is the seventh largest exporter of uranium in the world. After Kazakhstan, Uzbekistan also signed a deal with India in 2019 "for long term supply of uranium from the resource rich Central Asian country to power its domestic atomic reactors" (Chaudhury, 2019).

Going from Civil to Military, Military cooperation of India has been restricted only to military training in the region. The Indian foreign policy for Central Asia "Connect Central Asia Policy" was followed actively in 2015 as the Indian Prime Minister Narendra Modi visited all the five 
states of the region to focus on the priorities of cooperation in defense, energy and connectivity. PM Modi signed memorandum of understandings (MOUs) and agreements in the field of defense and military technical cooperation with Kyrgyzstan, Kazakhstan and Turkmenistan. In addition to bilateralism, India also supported multilateral engagements in the region, first - regional connectivity - second - multilateral cooperation with Central Asia and other external powers. For the regional connectivity, Modi visited Iran in 2016, where he signed an agreement with Iranian counterpart President Hassan Rohani to develop Chabahar port for India's gateway to Central Asia. On the multilateral engagements platform, India and Eurasian Economic Union (EEU) including two Central Asian states Kyrgyzstan and Kazakhstan held talks for multilateral cooperation. A joint study group has already submitted its report for the feasibility for the free trade agreement in 2017 (Menon \& Rajiv, 2019). So India has a broader vision of regional integration between the South-North to enhance and expand its role both in Central Asia and South Asia (CASA). 'Connect Central Asia Policy' is a key goal of India foreign policy to access Central Asia and further Eurasian region aiming to boost trade and economic ties. For the Indian vision, Afghanistan might be a country to help India connecting to the north through enabling Chabahar port.

Another research on the subject has observed that Afghanistan can be a thriving "transit" country. But, for that the country has to move its economy forward on fast track. However the Great game resulting in the intense competition among the U.S., Russia and Iran to shape the pipeline politics of Central Asia and the Caspian Sea has not been beneficial for the region. In this chess game, the U.S. sought to cut the Russians and Iranians out of the pipeline routes, and Moscow and Teheran in turn played hard ball so as not to let any other plans succeed. Realizing the futility of this competition, the U.S., Russia and Iran have now cooperated, openly or tacitly, in controlling the Taliban. If they can extend the cooperation towards an efficient exploitation of the Central Asian natural gas resources, it would be possible to move away from the metaphor of the Great Game. The biggest beneficiary of such a shift has been Afghanistan. A network of gas pipelines and highways crisscrossing Afghanistan could connect the former Russian republics of Central Asia with the energy markets in the subcontinent, and link the gas grids of Iran and inner Asia. The pie is large enough to ensure a stake for each of the key players. India as a party interacting with USA, Russia and Iran can play a great stabilizing role and ensure stability and prosperity in the region and in turn bolster its own economy (Mohan, 2001). 


\section{Pakistan}

Pakistan neighboring both Afghanistan and India had historic cultural relations with Central Asia in the past when the present day Pakistan was the part of Afghanistan-India undivided territories. People from Central Asia and South Asia had good trade links with Pakistan; Peshawar (historic part of Afghanistan) was the focal point in doing business with each other and the language of Hindko of Peshawar served for trading communication between South Asian and Central Asian (CASA) traders and businessmen, and the trade flourished from Samarkand to Multan and to Lahore route (Sofi, 2019). Somehow present-day Pakistan failed to develop relations with Central Asia after 1990s. The geo-economics and strategic location of the Central Asia and the contests between India and Pakistan are the prime factors that have distracted Pakistan's attention. However, it has played important role towards Central Asian states in recent years. The geostrategic advantage of Pakistan is its shorter distance for the landlocked Central Asia to have access to the sea for global trade and also to transfer its additional gas and electricity to Pakistan and India via Afghanistan. The Karachi port is $2,720 \mathrm{~km}$ away from Central Asia which is the closest port than the ports of Bandar Abbas (3,400 km) and the Russian ports Vladivostok and Rostov on the Don (9,500 km and 4,300 km away) (Javed \& Dashti, 2016). As per Adnan and Fatima, "Pakistani ports of Karachi, Pasni and Gwadar which are around $1600 \mathrm{~km}$ away from Central Asian Republics are the shortest routes for economic links between Pakistan and Central Asian Republics.” (Adnan \& Fatima, 2015, p. 192)

Pakistan's strategic and economic interests in Central Asia date back to the establishment of a Regional Development Organization founded in 1964, which became the Economic Cooperation Organization (ECO) in 1985 that included Iran, Pakistan and Turkey as members who were strongest allies of US during Cold War period. In 1992, Afghanistan and the five Central Asia Republics became members of the Economic Cooperation Organization (ECO) and one Caucasus country - Azerbaijan - joined the organization. ECO aimed at building a common market for goods, services and multilateral engagements amongst Muslim countries. For Pakistan,

hopes were revived to have access to the natural resources of the region while exporting textiles, telecommunications equipment and machinery but failed in doing agreements with the five republics because of regional problems and its own weaker economy. (Fair, 2008) 
In 1990s, Pakistan attempts to have close bilateral relations with Central Asia failed because of instability caused by its own continued political meddling in Afghanistan that led to wide regional insecurity. Frankly, this predicament created by Pakistani establishment affected the entire region, by design or by fault one can decide.

Interestingly, Pakistan, in fact, did not stop its diplomatic attempts towards Central Asia for the bilateral and multilateral cooperation. A high level delegation from Pakistan to Russia and Central Asia in the end of 2001, covered bilateral issues (Fair, 2008); Pakistan lent $\$ 10$ million in credit to Kazakhstan, Kyrgyzstan and Tajikistan establishing joint ventures in cottons, textiles, garments, pharmaceuticals, engineering goods, surgical instruments and telecommunications equipment. According to Fair (2008), Pakistan and Uzbekistan cooperation seemed better with agreements to improve bilateral engagements. Pakistan also signed agreements with Tajikistan and Kyrgyzstan to import hydroelectric power. But these all efforts were limited on account of the instability in Afghanistan and Tajikistan.

Pakistan also saw itself as a focal point for reaching out to strategic and economic interests in Central Asia. From another angle, with the China's investment in Gwadar, Pakistan is planning to be connected with Central Asia through Karakorum highway linking Pakistan to China and onward to Central Asia. For this purpose, "Pakistan, China, Kazakhstan and Kyrgyzstan signed a quadrilateral trade and transit agreement that has worked since 2004.” (Fair, 2008, pp. 222-223). After India, Pakistan expectations are high in the field of energy and electricity to meet its domestic needs, for which Afghanistan is seen as a helpful factor in connectivity. It seeks to reach Central Asia energy reserves through Afghanistan which is the shortest path, particularly suiting to Pakistan. So, its substantial interests in CARs are to avail strategic advantage in order to enrich its economic role as well as build a stronger partnership. Access to gas, fuel, oil and power of Central Asia via Afghanistan will change the region into a big market in case political disputes between Afghanistan, Pakistan and India are ignored relatively.

Unfortunately, the biggest obstacle to creating a Eurasian land bridge in Afghanistan lies in Pakistan. For the last decade Pakistan has nursed ambitions not only of creating a pliable regime in Kabul, but also to eventually gain control over the Afghan land bridge. But Pakistan's romance in Afghanistan, with a view to find a strategic depth in Afghanistan and exploit its geopolitical location, have come to a disastrous end. Pakistan, however, hopes that it will be able to take 
advantage of the political geography of the region only if it is ready to transform itself into a 'bridge state' (Mohan, 2001a). Mohan has rightly stated that:

The attempt of the international community must be to encourage Pakistan to become a transit state along with Afghanistan. The U.S. success in Afghanistan will depend on the ability to transform Pakistan into a state that is in harmony with its neighbors, sheds its obsession with gaining more territory and seeks prosperity through open borders and expanding trade linkages.

\section{Afghanistan}

Four decades of instability of Afghanistan has not affected its historic and geostrategic significance in the region. For Afghanistan, the ancient prominence as crossroads of Asia is very much alive. In recent times, the discourse on Afghanistan as connecting point has become more pronounced amongst state actors particularly between the South-North. In fact, the landlocked Afghanistan geostrategic location looks like a global route for trade and transit, and energy transition - from north to south. Strategically, the highest point of the country - Hindu Kush - that separates Central Asia from Indus Valley has been noted duly by Geographer Chapman G. P. (2009), who states:

It is crossed by a few passes, linking Chitral (in modern Pakistan) with northern Afghanistan, and by the Salang, joining southern and northern Afghanistan. From the plateau area there are two principal routes down to the Indus plains - the Khyber Pass just south of the Kabul River and, much further south, the Bolan Pass leading down from Quetta. In the British period these two were known simply as the Northern Route and the Southern Route. The first led to Punjab, and the second to Sindh. (p. 89)

Afghanistan is a key factor for bringing the concept of regional connectivity in action to develop the frameworks of bilateral and multilateral engagements amongst a number of states. Seen in perspective, Afghanistan as a land bridge includes Pakistan, India, Iran, the five Central Asian republics and further Eurasian region through enabling Karachi, Gawadar and Chabahar ports. It can provide for multiple opportunities in the fields of energy transport, trade and transit, transport networks, communication and exchange of goods. Furthermore, the historic significance of crossroads of Asia is being revived to play a broader role in the region, connecting Afghanistan to South Asia, Central Asia, Middle East and Far East. The multilateral efforts such as the Regional 
Economic Cooperation Conference on Afghanistan (RECCA, 2017) pointed out some key energy projects like TAPI, CASA-100 and TAP-500 which are underway. Furthermore, transport networks projects like Belt-and-Road initiative and Afghanistan Lapis-Lazuli Transit, Chabahar International Transport and Transit Corridor, Five Nations Railway Corridor, Afghanistan Rail Network and Trans-Hindukush Road Connectivity are major infrastructural projects of connectivity that have been discussed in key summits of RECCA (RECCA. 2017). Afghanistan factor of regional connectivity is an asset in the region for neighboring countries to come up with regional trade and transit vision. Economic aims of intra-regional states which are shared and interlinked require a viable engagement to be followed and achieved. Similarly, Afghanistan has always displayed interest in being transformed into economic circle in the region, in order to pursue the same demands and needs felt on regional level today. As per President Mohammad Ashraf Ghani:

we want contiguity, not discontiguity! We want progress, not extremism and death! Because the more we increase our cooperation, the more mutual welfare gets improved." (Mohammad Ashraf Ghani, 2017, para. 12)

President Mohammad Ashraf Ghani, since he has come to power, has focused on regional integration for the quality of life and economic development to engage with regional actors. According to him, creating cooperative connection produces a network of development which leads to prosperity and terminate poverty of the people in society (Danish, 2017).

Hence, Afghanistan geostrategic location holds the capability of playing comprehensive role by connecting Central Asia with South Asia as an economic corridor. It is the best and shortest corridor through Afghanistan to Gwadar and Karachi ports of Pakistan and Chabahar port of Iran further to the Indian subcontinent. It will help Pakistan and India to benefit from Central Asia energy resources to boost their economic growth broadly by access to Central Asia's bigger market. Similarly, Central Asia and Afghanistan will be able to have access South Asia trading market through Pakistan easily. It's for Pakistan to understand the importance of this huge potential. 


\section{Regional Connectivity: Challenges and Opportunities}

\section{Opportunities}

Since 1991, Central Asia has attracted regional and global attention because of having abundant natural minerals, energy and hydropower resources. It has provided various opportunities to the regional and global powers to encourage investments, enterprises and create facilities to develop regional and global engagements. There have been various challenges to economic opportunities which will be pointed out later.

Afghanistan, situated as it is, is an appropriate corridor for both the regions. The projects of energy transition provide greater opportunities for the entire region of south-north. Great economic opportunities of regional integration that are being passed through Afghanistan from north to south can be described in brief.

\section{TAPI Project}

TAPI is a regional gas transit project that includes Turkmenistan, Afghanistan, Pakistan and India. The concept of gas transmission from Central Asia to South Asia became a considerable topic of discussion in 1990s and it was revived in 2003 with the support of Asian Development Bank (ADB). India joined TAPI in 2008 to be access Turkmenistan natural gas along with Pakistan. The aim of the TAPI project is to export 33 billion cubic meter (BCM) of natural gas from Turkmenistan to South Asia annually. (Ministry of Mines, 2018). The TAPI project will lay down 1,814 kilometers of gas pipelines out of which 814 kilometers will pass through Afghanistan, that is from Turkmenistan, first entry of the pipeline to Herat furthering to Farah, Nimroz, Helmand and through Kandahar strategic provinces of Afghanistan. The pipeline will be constructed alongside Herat-Kandahar highway of western Afghanistan where it will lead towards Quetta and Multan, in Pakistan. The last destination of the pipeline will be the town of Fazilka of India near to Pakistan border (Sirat, S. 2018).

Through TAPI, Afghanistan will earn $\$ 400$ million annually. It will create employment opportunities, facilitate development of infrastructure, and will pave the way to domestic production. Furthermore, in the first decade, Afghanistan will get 500 million cubic meters of gas; in the second decade, it will get 1 billion cubic meters of gas and in the third decade, it will get 1.5 
billion cubic meters of gas from the pipeline. India and Pakistan will meet their needs of gas and will promote investment and industry. (Ministry of Mines, 2018)

\section{CASA-1000 Project}

The CASA-1000, a corridor of Central and South Asia is a major project of electricity transfer. It connects four countries; Kyrgyzstan, Tajikistan, Afghanistan and Pakistan through power grids. In 2011, A Memorandum of Understanding was signed by the four countries in Bishkek, Kyrgyzstan (RECCA, n.d.). The final agreement for the electricity transmission of the project was signed by four countries in Istanbul, in 2015. Based on the agreement, 1300 megawatts electricity will be transferred to Afghanistan and Pakistan, of which 300 megawatts will be received by Afghanistan (Tolo News, 2015). CASA-1000 project will totally cover 1,250 kilometers between the four countries, to be completed by 2022. Afghanistan has started the work of implementation on the project in 2020 (Pajhwok, 2020). CASA-1000 will propel economic development where the two electricity starved countries aim to fill the gap of power shortages, open the way to ensure sustainable growth, encourage national economies by creating opportunities and building regional cooperation. India is planning to join the CASA-1000 four countries electricity project. It would be a big landmark development for the region when India connects through CASA-1000 project too.

\section{TAP-500 Project}

TAP-500 is a $500 \mathrm{KV}$ power transmission energy network of Turkmenistan, Afghanistan and Pakistan. The aim of the project is to transfer electricity through Afghanistan and further to Pakistan in order to meet the shortages of power in their respective countries. The Memorandum of Understanding (MOU) was signed by three countries in December 2015, as per Da Afghanistan Breshna Sherkat (DABS, n.d.). TAP-500 is a major project that has the capacity to provide 1,700 megawatts electricity to Pakistan, subsequently planned to be raised to 4000 megawatts. The project transmission line is through Herat and Kandahar along with TAPI gas pipeline onward to Pakistan (Saeedi \& Kadyrova, 2018). After CASA-1000, this is another big project through which the three nations are connected via electricity to boost their economies and motivate more investments as well as light people homes who don't have access to electricity in their respective countries. 


\section{TUTAP}

TUTAP is another mega electricity project consisting of Tajikistan, Uzbekistan, Turkmenistan, Afghanistan and Pakistan. It aims to transfer surplus power from Central Asia to South Asia. Afghanistan and Pakistan are to be seen as major beneficiaries. TUTAP project will be implemented along with TAP-500 project which will create a unified grid in Afghanistan where it is distributed into various provinces in the country (Saleem, 2018).

Overall, all projects will be implemented in different periods of time, possibly to end by 2025 . These massive projects will play effective role in shaping the region, strengthening economic and diplomatic ties between the states. Also, it will boost national economies of states and will create as many possible opportunities to the people of South Asia.

\section{Chabahar Port Project}

Chabahar port is a largest project connecting India through Iran and Afghanistan with Central Asia. It is the alternative passage of Gwadar and Karachi ports of Pakistan in the region. After a decade of negotiations that started in 2003, the three-nation agreement, finally, was signed on May 24, 2016 with the investment of India at $\$ 500$ million in Phase one. The purpose of the agreement was to develop the strategic port and to build a transport and trade corridor through Afghanistan to connect India with Central Asia and beyond. Chabahar port is located in southern Iran's Sistan-Balochistan province linking up to Zarange, Nimroz in Afghanistan, and a 218 kilometers Road of Zarange-Delaram has also been constructed by India in 2009. The Zarange-Delaram passage will give access to India to connect major cities of Herat, Kandahar, Kabul and Mazar-e-Sharif in Afghanistan and onward with Central Asia (Hindustan Times, 2016).

After the inauguration of first phase of Chabahar port in 2017, India formally took over the Chabahar port operations based on trilateral agreement between India, Iran and Afghanistan on 24 December 2018. By providing facilitations of ports, road and railway networks, Chabahar port would enhance connectivity among three countries. Chabahar port is seen an easy access for India to counter Pakistan's Gawadar port located at 80 kilometers away. Besides serving as the Indian gateway to Central Asia, Chabahar port is to play important role between South-North transport corridors through Afghanistan to Central Asia then further to Russia and Europe altogether (India Today, 2019). 


\section{Challenges}

From the view of strategic location, Afghanistan is an attractive and strategically important interface for regional and global powers. Despite of Afghanistan's geo significance, the country has been suffering countless challenges causing instability.

Afghanistan has to engage with regional powers to tackle those challenges existing either in Afghanistan or in the region, and also concentrate on building national infrastructure. For example, constructing railways and highways provide help with the vision of regional connectivity. As Safi and Alizadah (2019) highlighted (who are founders of Organization for Policy Research and Development Studies, a think-tank based in Kabul) that one of the main challenge against regional connectivity in Afghanistan has been long term instability and political conflict. Meanwhile, the infrastructure deficit is seen as one of the basic challenges that needs to be addressed for trade, and transit connectivity as well as to promote investment and multilateral engagements.

Likewise, reforms in financial and banking institutions are needed so as to ensure safe and standardized transactions to towards economic activities. The lack of growth in export sector is another challenge to address.

Political frailty of the government in its relations with neighboring countries is another bottleneck. The researchers and policy makers' point out that the Afghanistan-Pakistan Transit Trade Agreement (APTTA) was signed in 2010 for five years but still has not been renewed after it expired in 2015 (Safi \& Alizada, 2019).

These challenges nullify, to some extent, advantage of Afghanistan's strategic position and undermines its potential role for regional integration. Other challenges like deficit of technical capacities and the ongoing war have caused of delays in mega regional projects and infrastructure development. One of the key reasons for ongoing armed and terrorist clashes is also the meddling of interested states in Afghanistan's domestic affairs. Afghanistan and its six neighbors have signed the Kabul Declaration on December 22, 2002 based on good neighborly relations including China, Pakistan, Iran, Tajikistan, Turkmenistan and Uzbekistan. All six countries "determined that the people of Afghanistan should enjoy security, stability, prosperity, territorial integrity, democracy and human rights after so many years of conflict, suffering, and deprivation" (Haidari, 2018, para. 2). Still the war has been on, and concrete measures with support of regional colleagues and friends needs to be taken. 
It is also to be noted that India-Pakistan conflict and continued competition have led to slow progress in the region towards regional connectivity. It has provoked proxy wars in the region particularly in Afghanistan, restricting the process of regional connectivity. Pakistan has to allow India to have access through to Afghanistan and Central Asia, putting the political issues aside.

That is one of the reasons; India has viewed with some suspicion the various proposals for transborder pipelines within its Western neighborhood. India needs to see these pipeline projects - that connect it with Iran through Pakistan, or integrate Central Asia to the Indian market through Afghanistan and Pakistan - as vehicles to transform the region. As the biggest economic force and the largest consumption centre for energy, India should have a natural say in how these projects are structured (Mohan, 2001b). Instead of stepping back, Pakistan should leverage these projects to nudge the economies of all the stakeholders in a positive direction.

In additions to the above, various terror groups are still active in the region which has made the region destabilized. For example, terror groups and networks have open activities in Pakistan, Afghanistan and Central Asia. Joint measures are needed to be taken against terrorism and all other armed groups. They are fundamentally perceived as challenges to economic cooperation and regional integration. And, in the presence of instability and insecurity, the concept of regionalism can't be implemented with success. USA needs to be cognizant of this fact and adequately cater for it while withdrawing from Afghanistan, ensuring an appropriate role for countries with capabilities to bring stability and prosperity to the region. .

Despite these challenges, Afghanistan from own side has constituted and adopted some "commercial and investment laws including a company law, consumer protection law, competition law, partnership law, and arbitration law, among others" (Haidari, 2018, para. 9). It needs to focus on creating facilities to develop infrastructures and boost Afghanistan's economy, open the path to foreigners to invest and transform the strategic location of the country as a regional integration and connectivity hub. Regional countries have to work closely with Afghanistan to terminate the existing challenges, particularly ongoing conflict in the country in order to enable the opportunities for cooperation and engagement. 


\section{Conclusion}

Central Asia has enjoyed abundant natural energy resources. On the other hand, South Asia has been suffering of energy shortages than any other region. It imports energy like gas, hydrocarbons, uranium, oil and electricity to meet its needs and takes advantage from it in nuclear plants, industrial sectors, investments and so on. In particular Pakistan and India can buy gas, power and energy from the five republics of the region. However, Afghanistan is the only country to connect the two regions directly through trade and transit approach. Afghanistan, due to its regional prestige, can play cooperative role to provide opportunities for intra-regional interactions and trade markets.

Central Asian and South Asian countries can collectively work towards addressing existing challenges and exploit economic opportunities for common good. These states need to jointly put historic conflicts aside giving priority to economic cooperation and collaboration by supporting Afghan Peace Process to end the four decades war in Afghanistan permanently. Should that happen, a new era of economic development will dawn in the North-South Asia, helping millions of people to find opportunities for a wholesome life.

Afghanistan, courtesy its geo-strategic location, has the unique potential to serve as the land bridge between North-South Asia, extending further to eastern Europe. Supporting the peace process and return of stability in Afghanistan, therefore, holds momentous significance to all the countries in central and South Asia.

However, further research is needed to determine impacts of following probable issues on the concepts discussed in the paper:-

a) Collapse of administration in Afghanistan, post withdrawal for US forces.

b) Disturbances in POK region and slowing down of China Pakistan Economic Corridor Project

c) Border skirmishes in and around the region

d) Deterioration in Iran-USA relations 


\section{References}

1. Adnan, M., \& Fatima, B. (2015). Strategic and economic interests of Pakistan and India in Central Asia. A Research Journal of South Asian Studies. 30 (3), 187-200.

2. Archiwal. (2019). Overwhelming majority of Afghans has a positive perception of India. A. Ranjan (ed.), India in South Asia, (pp. 123-131). https://doi.org/10.1007/978-981-132020-0_8

3. Asian Asia relations. International Journal of Research in Social Sciences, 8 (3), p. 16, Retrieved Development Bank, (2010). Central Asia Atlas for natural resources. Retrieved November 3, 2020, from Asian Development Bank Website: https://www.adb.org/publications/central-asia-atlas-natural-resources

4. Bhat, A. A., Mubarik, M., \& Kushwaha, R. P. (2018). Afghanistan factor in India-Central from https://www.ijmra.us/project\%20doc/2018/IJRSS_MARCH2018/IJMRA-13386.pdf

5. Chapman, G. P. (2009). The geopolitics of South Asia from early empires to the nuclear age: Securing the empire (3 rd.). Retrieved from https://b-ok.asia/book/1000034/ab50a

6. Chaudhury, D. R. (2019, January 19). India inks deal to get uranium supply from Uzbekistan. The Economic Times. Retrieved November 8, 2020, from https:///m.economictimes.com/news/defence/india-inks-deal-to-get-uranium-supplyfrom-uzbekistan/articleshow/67596635.cms

7. Da Afghanistan Breshna Sherkat. (n.d.). TAPI-TAP: Regional economic cooperation $\begin{array}{lllll}\text { corridor. } & \text { Retrieved } & \text { November } & 10, & \text { 2020, }\end{array}$ https://main.dabs.af/News/NewsDetail/1353

8. Danish, Z. (2017). Afghanistan; connectivity chapter in the region. Retrieved November 8, 2020, from https://ocs.gov.af/en/article_details/139

9. Dhaka, A. (n.d.). South Asia and Central Asia: Geopolitical dynamics: the geopolitical theory. Jaipur, India: Mangal Deep Publications Jaipur.

10. Fair, C.C. (2008). Pakistan's Relations with Central Asia: Is Past Prologue?, Journal of Strategic Studies, 31(2), 201-227, https://doi.org/10.1080/01402390801940344

11. Haidari, M. A. (2018, January 26). A peaceful Afghanistan key to regional connectivity in South and Central Asia. The Diplomat. Retrieved November 12, 2020, from https://thediplomat.com/2018/01/a-peaceful-afghanistan-key-to-regional-connectivity-insouth-and-central-asia/ 
12. Hindustan Times. (2016, May 24). India, Iran and Afghanistan sign Chabahar port agreement. Hindustan Times. Retrieved November 11, 2020, from https://www.hindustantimes.com/india/india-iran-afghanistan-sign-chabahar-portagreement/story-2EytbKZeo6zeCIpR8WSuAO.html

13. India Today. (2019, January 8). Chabahar port begins commercial operations: Why Iran's port is important for India. India Today. Retrieved November 11, 2020 from https://www.indiatoday.in/education-today/gk-current-affairs/story/india-takes-overoperations-chabahar-port-iran-importance-1426057-2019-01-08

14. Javed, F., \& Dashti, A. A. (2016). Relations between Pakistan and Central Asian Republics: An analysis. Maarif Research Journal. (11),Pp. 67-78

15. Kaushiki, N. (2013). The New Great Game and India's Connect Central Asia Policy: Strategic Perspectives and Challenges. Journal of International and Area Studies, 20(2), 83-100. Retrieved November 3, 2020, from http://www.jstor.org/stable/43107259

16. Khan, I. (1998). Afghanistan: A geopolitical study. Central Asian Survey, 17 (3), 489-502. doi: https://doi.org/10.1080/02634939808401049

17. Kothari, R. K. (2018). India's strategic interests in Central Asia in the Post-Soviet years: Expanding vistas of partnership. Asian Journal of Political Science. 4 (1), Pp. 23-32.

18. McCauley, M. (2002). Afghanistan and central Asia a modern history: Afghanistan. London, England: Pearson Education Limited.

19. Menon, R., \& Rajiv, S. (2019). Realizing India's strategic interests in Central Asia. Retrieved November 5, 2020, from https://carnegieindia.org/2019/12/01/realizing-india-sstrategic-interests-in-central-asia-pub-80576

20. Ministry of Mines and Petroleum. (2018). TAPI project. Retrieved November 9, 2020, from https://momp.gov.af/tapi-project

21. Mohan C Raja (2001), The Hindu, Afghanistan as a land bridge , Retrieved from: https://www.mea.gov.in/articles-in-indianmedia.htm?dt1/18382/Afghanistan+as+a+land+bridge (accessed on 21 Apr 2021)

22. Pajhwok, (2020, February 6). Ghani inaugurates CASA-1000 project implementation. Pajhwok News Agency. Retrieved November 10, 2020, from https://www.pajhwok.com/en/2020/02/06/ghani-inaugurates-casa-1000-projectimplementation 
23. RECCA, (n.d.). Central Asia and South Asia (CASA-1000). Retrieved November 9, 2020, from http://recca.af/?page_id=1466

24. Regional Economic Cooperation Conference on Afghanistan. (2017). Deepening connectivity and expanding through investment and infrastructure and improving synergy: 2017. Retrieved November 9, 2020, from http://recca.af/wpcontent/uploads/2018/04/Digital-RECCA-Annual-Review-2017-11-04-2018.pdf

25. Saeedi, T., \& Kadyrova, R. (2018, February 26). Start of a new corridor - TAPI, TAP500, TAP fiber optic link, rail way. News Central Asia. Retrieved November 10, 2020, from http://www.newscentralasia.net/2018/02/26/start-of-a-new-corridor-tapi-tap500-tap-fiberoptic-link-railway-line/

26. Safi, M., \& Alizada, B. (2019, April 19). Afghanistan: Prospects and challenges to regional connectivity. The Diplomat. Retrieved November 12, 2020, from https://thediplomat.com/2019/04/afghanistan-prospects-and-challenges-to-regionalconnectivity/

27. Saleem, A. (2018). Central and South Asian Energy Projects: Prospects and Challenges for Pakistan. Strategic Studies, 38 (3), 57-71. doi:10.2307/48539384

28. Siyar, S. (2018, February 24). All you need to know about TAPI project. Tolo News. Retrieved November 9, 2020, from https://tolonews.com/afghanistan/all-you-need-knowabout-tapi-project

29. Sofi, M. D. (2019, January 15). The dynamics of Pakistan-Central Asia engagement. Daily Sabah. Retrieved November 9, 2020, from https://www.dailysabah.com/oped/2019/01/15/the-dynamics-of-pakistan-central-asia-engagement

30. Tolo. (2015, April 25). CASA-100 project signed. Tolo News. Retrieved November 10, 2020, from https://tolonews.com/business/casa-1000-project-signed-promising-majorrevenues-afghanistan 